\title{
Europe bids to pull US patent law into line $w$ ith first-to-file system
}

[LONDON] The European Commission (EC) and the United States are to reopen talks after more than a decade aimed at eventually harmonizing US patent law with that of most other countries.

The talks are part of the Transatlantic Economic Partnership, the regular bilateral trade negotiations between the EC and the United States.

A first round is expected to be held in Washington DC in the coming weeks, to be followed by a second round in Brussels later this year. Informal talks could start as early as next week at a meeting of the World Trade Organization in Geneva.

Whereas priority on patents is attributed in Europe on a 'first to file' basis, the US system is based on 'first to invent'. The legal ambiguities this can create lead to expensive legal squabbles to establish the paternity of inventions. The United States is the only country to have such a system.

A further difference is that in Europe a patent has to be applied for before publication, whereas in the United States a 12month post-publication grace period exists.

'First to file' has become the standard outside the United States because it is less complicated and costs less to process than applications based on first to invent, particularly if patent lawyers are employed by competing clients to prove that they were first to come up with a particular idea.

'First to file' is particularly popular with small companies and with lone inventors who, unaware of the requirements of US patent procedures, find that their attempts to patent discoveries in the United States run into difficulties if they lack well-kept laboratory notebooks that have been authenticated by witnesses.

The first-to-invent system is nonetheless staunchly defended in the United States by many small companies and inventors. William Respess, a senior vice-president of Ligand Pharmaceuticals in San Diego, California, argues that, under this system, the patent holder is genuinely the first person to come up with an idea.

The United States is unenthusiastic about harmonizing its patent laws with the rest of the world, partly because it believes them to be fairer to inventors and scientists by allowing them to publish their work before applying for a patent.

Harmonization was last attempted by the World Intellectual Property Organization a decade ago. But this slipped off the agenda when talks at the World Trade Organization led to the signing of the multilateral Trade

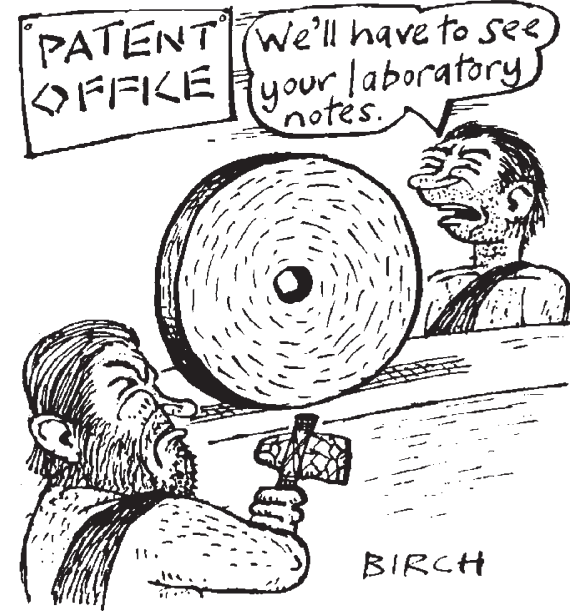

Related Aspects of Intellectual Property Rights (TRIPs) agreement.

An attempt to introduce first-to-file legislation in the United States in 1992 failed following strong opposition from small companies and inventors. Many large corporations, however, support a move to first-tofile law on the grounds that a single worldwide system will make the job of applying for patents easier.

An official at the EC in Brussels says that some progress is expected before the end of the year. But Dave Schmickel, patent and legal counsel for the Biotechnology Industry Organization in the United States, is one of many observers who believe that obtaining a change in US patent law could take "decades rather than years".

One leading US patent lawyer says that, if the United States were to move to a first-tofile system, inventors would expect to be allowed a grace period, as well as a mechanism for protecting the theft of an idea.

The EC has considered whether to adopt a grace period. But the idea is not popular, and the commission is reluctant to go down this road, partly because establishing patent paternity could be a recipe for expensive litigation (see Nature 395, 531; 1998).

A compromise may also have to be found on the issue of transparency in processing a patent application. Unlike countries in the European Union, patents in the United States are processed behind closed doors, which allows experimental and other details to be hidden from competitors.

But Ron James, research director of PPL Therapeutics, the Edinburgh-based company that holds the patent for Dolly the cloned sheep, says that a transparent system allows others to monitor what might be fraudulent applications.

The talks are being backed by Britain and other European countries which are looking to small biotechnology and informationtechnology businesses to become major contributors to economic growth.

Nick Scott-Ram, chair of the intellectual property advisory committee of Britain's BioIndustry Association, welcomes the moves towards harmonization. He says an increasing number of small and mediumsized companies are now aware of US patent requirements, such as the need to keep accurate records during the process of discovery.

But Scott-Ram says that such companies are equally concerned that the talks should result in progress on reducing the costs of applying for a US patent.

Ehsan Masood

\section{German call to invest more in technology}

[MUNICH] German companies risk an erosion of their 20 per cent share of the world pharmaceutical market unless they invest more in new technology, according to a new report.

The report - commissioned by the federal research ministry from six independent institutes for economic and innovation research - concludes that companies need to increase their investment in biochemistry, bioinformatics and combinatorial chemistry.

It also reveals that public and private funding of research in Germany is only now beginning to recover from large cuts made in the first half of the decade.

Support for research and development fell from around 3 per cent of gross domestic product (GDP) in 1990 to 2.3 per cent in 1996. Although public funding has remained relatively flat, industry has increased $\mathrm{R} \& \mathrm{D}$ investment by 10 per cent between 1995 and 1997. Research funding is now 2.4 per cent of GDP, compared with 3.6 per cent in Sweden, 2.8 per cent in Korea and Finland, 2.7 per cent in Switzerland and 2.6 per cent in the United States.

The report, Germany's Technological Capacity and Efficiency, identifies the country's strengths as being in solid-state physics, semiconductors, material science, polymer research, measurement technology and astrophysics. But it still lags behind Britain, Japan and the United States in key technologies such as software development and biotechnology. Quirin Schiermeier 